\title{
The homeodomain protein Vax1 is required for axon guidance and major tract formation in the developing forebrain
}

\author{
Stefano Bertuzzi, ${ }^{1}$ Robert Hindges, ${ }^{1}$ Stina H. Mui, ${ }^{1,2}$ Dennis D.M. O'Leary, ${ }^{1}$ and Greg Lemke ${ }^{1,3}$ \\ ${ }^{1}$ Molecular Neurobiology Laboratory, The Salk Institute for Biological Studies, La Jolla, California 92037 USA; ${ }^{2}$ Department \\ of Neurosciences, University of California at San Diego, La Jolla, California 92093 USA
}

The homeodomain protein Vax1 is expressed in a highly circumscribed set of cells at the ventral anterior midline of the embryonic CNS. These cells populate the choroid fissure of the optic disk, the body of the optic stalk and nerve, the optic chiasm and ventral diencephalon, and the anterior midline zones that abut developing commissural tracts. We have generated mutant mice that lack Vax1. In these mice (1) the optic disks fail to close, leading to coloboma and loss of the eye-nerve boundary; (2) optic nerve glia fail to associate with and appear to repulse ingrowing retinal axons, resulting in a fascicle of axons that are completely segregated from optic nerve astrocytes; (3) retinal axons fail to penetrate the brain in significant numbers and fail to form an optic chiasm; and (4) axons in multiple commissural tracts of the anterior CNS, including the corpus callosum and the hippocampal and anterior commissures, fail to cross the midline. These axon guidance defects do not result from the death of normally $\mathrm{Vax}^{+}$midline cells but, instead, correlate with markedly diminished expression of attractive guidance cues in these cells. Vax1 therefore regulates the guidance properties of a set of anterior midline cells that orchestrate axon trajectories in the developing mammalian forebrain.

[Key Words: Homeobox; axon guidance; glia; optic nerve; midline; netrin]

Received May 27, 1999; revised version accepted October 14, 1999.

Glial cells have essential axon guidance roles in the developing Drosophila CNS, notably in the control of pathway choice as axonal growth cones encounter the midline glia of the ventral nerve cord (Jacobs and Goodman 1989; Klambt et al. 1991; Hummel et al. 1997). Several of the midline glial genes that underly this control have been identified and cloned (Rothberg et al. 1990; Tear et al. 1996; Kidd et al. 1999), and have been found to encode chemoattractants such as the Netrins (Mitchell et al. 1996; Winberg et al. 1998), dual-function chemorepellents such as Slit (Battye et al. 1999; Kidd et al. 1999), and proteins such as Commissureless, which appear to modulate the ability of growth cones to respond to midline guidance cues (Tear et al. 1996). Although the molecular details of signal presentation by midline glia and their interpretation by axonal growth cones are still being worked out, the axon guidance defects seen in mutants of the slit, roundabout, netrin $A$ and $B$, commissureless, and frazzled genes clearly demonstrate that

${ }^{3}$ Corresponding author.

E-MAIL lemke@salk.edu; FAX (858) 455-6138. growth cone navigation at the ventral midline is a combinatorial function of attractive and repulsive guidance cues provided by midline glia, and of the differential ability of commissural and longitudinal axons to respond to these cues as their growth cones approach and cross the midline (Zinn and Sun 1999).

The extent to which vertebrate glia may have similar axon guidance roles during neural development is less well understood in molecular terms, although the pioneering position and intimate axonal association of early glia at CNS midline structures such as the optic chiasm and corpus callosum has prompted considerable conjecture in this regard (Silver 1993; Marcus et al. 1995; Mason and Stretavan 1997). Detailed observations of axonal projections into and through the developing mouse optic chiasm, for example, have suggested that age-dependent variations in the cues provided by morphologically and molecularly distinct populations of midline glial cells in the ventral diencephalon control the development and interhemispheric decussation of axons projecting from the retina to the superior colliculus (Marcus and Mason 1995; Marcus et al. 1995, 1999; Wang et al. 1995). Similarly, studies in the embryonic cat, rat, and mouse brain 
have suggested that early midline astroglia provide the substrate for the formation of commissural fiber tracts, such as the corpus callosum and the anterior and hippocampal commissures, which cross the midline and thereby connect the two hemispheres of the developing mammalian forebrain (Silver and Ogawa 1983; Silver 1993; Silver et al. 1993). Netrin-1 (Serafini et al. 1996; Livesey and Hunt 1997) and mammalian Slit proteins (Li et al. 1999; Nguyen Ba-Charvet 1999; Wu et al. 1999) are expressed in regions populated by these midline glia.

The important issue of upstream transcriptional regulation of midline differentiation, particularly with regard to the regulated expression of Netrins, Slits, or other guidance cues, has thus far received limited attention. The ETS domain transcription factor Pointed (Klambt 1993), the POU domain protein Drifter (Anderson et al. 1995), and the SOX-related transcription factor Dichaete (Soriano and Russell 1998) are all expressed in early midline glia in Drosophila, and are known to be required for their normal differentiation, as evidenced by fused commissures in the ventral nerve cords of pointed, drifter, and Dichaete mutants. However, the molecular basis of the axon guidance phenotypes seen in these mutants is largely uncharacterized with respect to the expression of guidance cues. Mutational analyses of one vertebrate gene product expressed by glial cells of the developing optic nerve- the Paired domain transcription factor Pax2 (Dressler et al. 1990; Torres et al. 1996) and its zebrafish homolog Pax2.1 [No isthmus (Noi)] (Macdonald et al. 1997; Pfeffer et al. 1998)-have demonstrated that this protein is essential for normal axon growth within the nerve. An important guidance cue that is lost in the optic nerve astroglia of the Noi mutants is Netrin-1 (Macdonald et al. 1997). However, Pax2 is not expressed by the specialized glia that appear to guide midline axon crossing in the brain proper, for example, those at the corpus callosum and the anterior commissure (Torres et al. 1996; Macdonald et al. 1997; see Fig. 2, below), and therefore cannot function as a direct regulator of glial differentiation at these critical midline positions.

Recently, a new candidate regulator of midline differentiation in vertebrates-a homeodomain transcription factor designated Vax1-has been identified (Hallonet et al. 1998). The amino acid sequence of the homeodomain of this protein defines a new homeodomain subfamily whose members are most similar to the Drosophila protein Empty spiracles (Ems) and its related vertebrate homologs Emx-1 and Emx-2 (Hallonet et al. 1998; S. Bertuzzi and G. Lemke, unpubl.). In vivo, expression of $\operatorname{Vax}$ 1 is highly restricted to ventral anterior regions of the developing CNS (Hallonet et al. 1998; see Fig. 2, below), including the glial precursor cells of the optic stalk and their descendent astrocytes of the optic nerve, and regions containing the glia that are thought to guide the formation of midline commissural tracts. We cloned Vax1 from cultured rat Schwann cells, the principal glial cells of the vertebrate peripheral nervous system, although we have not observed Vaxl expression in any developing Schwann cell population in vivo. In cell culture, the expression of Vax1 mRNA is highly restricted to glial cells and glial cell lines (S. Bertuzzi and G. Lemke, unpubl.).

We have investigated the function of Vax1 by engineering loss-of-function mutations in the mouse. Among several possibilities, we sought to determine whether Vax1 (1) regulates the development, proliferation, or survival of the midline cells in which it is expressed; (2) functions to pattern the developing forebrain along the medial-lateral, dorsal-ventral, or anterior-posterior axes; or (3) controls the axon guidance properties of midline cells through upstream regulation of the genes encoding guidance cues. We find that Vax1 mutants exhibit no obvious deficiencies in midline cell number and, at most, modest defects in axial patterning at the midline. In contrast, these mutants display profound defects in axon guidance in the optic nerve and across the ventral anterior midline of the forebrain, many of which may be accounted for by the loss of appropriate axon guidance cues at the midline.

\section{Results}

\section{Targeting the Vax1 locus}

We replaced the wild-type $\operatorname{Vax} 1$ gene with a deleted gene by homologous recombination in mouse embryonic stem (ES) cells (Fig. 1), and used these ES cells to generate mice that lack Vax1, all by standard protocols (see Materials and Methods). The targeting vector for $\operatorname{Vax} 1$ inactivation (Fig. 1A) deletes a 2.2-kb BamHI segment of DNA that contains exons encoding the initiator ATG together with the first 166 amino-terminal residues of the protein, including the first 46 amino acids of the 60-residue homeodomain (predicted $\alpha$ helices 1 and 2). Amino acids equivalent to these latter residues are essential for the function of all known homeodomain transcription factors. In addition, mice carrying two copies of the diagrammed mutation do not express detectable Vax1 mRNA (Fig. 1C). For these reasons, the $\operatorname{Vax} 1^{-/-}$ mice described below almost certainly correspond to complete loss-of-function mutants.

\section{Defects in axon guidance and glial interaction in the $\mathrm{Vax}^{-/-}$optic stalk and nerve}

Vax1 mRNA is first detected in the mouse embryo at embryonic day (E)8, in the anterior neural ridge and adjacent ectoderm (Hallonet et al. 1998; S. Bertuzzi and G. Lemke, unpubl.). By E10.5, this expression coalesces into the optic disks and optic stalks, the olfactory placodes, and the extreme rostral end of the neural tube (Fig. 2A). Vax1 persists in derivatives of the former and latter domains into late embryogenesis, by which time expression is prominent in glial cells of the optic nerve and in cells of the rostral diencephalon (presumptive hypothalamus) (Fig. 2B). In the optic stalk, Vax1 is unambiguously the product of glial cell precursors, because the only neural cells that develop in situ from this segment of the neuroepithelium are the astrocytes that will populate the body of the mature optic nerve; the oligodendrocytes 
Figure 1. Inactivation of the mouse Vax1 gene. (A) Structure of the mouse Vax1 gene, the targeting vector for inactivation, and the recombined allele. Sequences that encode the Vax 1 homeodomain are contained in the second and third exons diagrammed, and are indicated in black. The first diagrammed exon contains the $\operatorname{Vax} 1$ initiator ATG. The first and second exons are deleted and replaced with a G418 resistance cassette (neo) in the mutant allele, and a thymidine kinase cassette $(t k)$ was used to select against nonhomologous recombinants (see Materials and Methods). The positions of the $5^{\prime}$ and $3^{\prime}$ probes used to assess homologous recombination of the left and right arms are indicated. (B) BamHI; (H) HindIII; (S) SacI. (B) Southern blot of HindIII-digested genomic DNA from wild-type $(+\mid$ $+\mid$, heterozygous mutant $(+/-)$, and homozygous mutant $(-/-)$ mice, hybridized with the $3^{\prime}$ probe indicated in $A$. $(C)$ Lack of Vax1 transcript in the subventricular zone of the ventral diencephalon of E13.5 mutant mice (-/-), as detected by in situ hybridization (see Material and Methods).

\section{A}
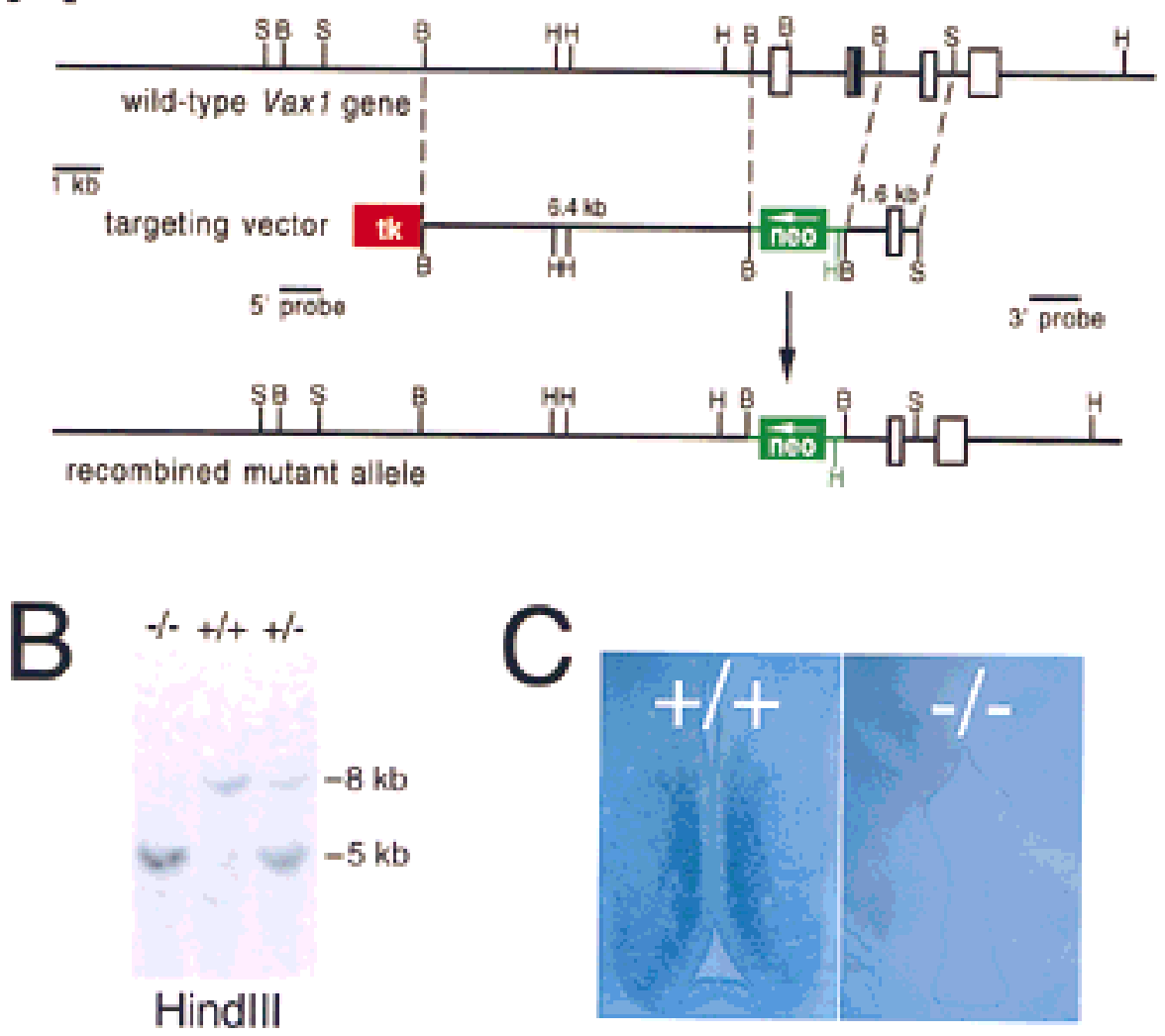

that myelinate the axons of the mature nerve develop from precursors that migrate into the nerve late in embryogenesis (beginning at E15) from germinal centers in the brain proper (Small et al. 1987; Raff 1989; Ono et al. 1997; Mi and Barres 1999). The prominent presence of Vax1 in the presumptive hypothalamus is a feature that distinguishes this gene from Pax2 in terms of both expression (Fig. 2B,C) and mutant phenotype (see below).

Loss of Vax1 from the glial precursors of the optic stalk leads to obvious perturbations in retinal ganglion cell (RGC) axonogenesis and axon-glial association (Fig.
3). By E13.5, wild-type RGC axons have extended through the stalk and been invested extensively by proliferating glial precursors (Fig. 3A). Normal numbers of axons are also present in the optic stalk by E13.5 in Vax $1^{-/-}$mutants; however, their growth is invariably constrained to a restricted cross-segment of the mutant stalk, from which the glial precursors are entirely excluded (Fig. 3B). These precursors normally give rise to the optic nerve astrocytes that, by late embryogenesis, are intimately associated with all RGC axons in wildtype mice (Fig. 3C); in the mutants, however, RGC axons

Figure 2. Vax1 and Pax2 mRNA expression in the developing brain. (A) Vax1 mRNA in an E10.5 mouse embryo, detected by whole-mount in situ hybridization, is evident in the optic stalk (os, bracket), optic disk (od), olfactory pit (op), and lamina terminalis (lt). The position of the neural retina, which does not express Vax1, is indicated by the circle. The surface boundaries of the telencephalon (tl), midbrain $(\mathrm{mb})$, and isthmus (is) are indicated by the broken lines. The CNS midline is indicated by the solid white line in this and subsequent panels. (B) Vax1 mRNA ${ }^{33}$ P-radiolabeled in situ), in a frontal section through the CNS of an E18.5 embryo, is expressed by the glial cells
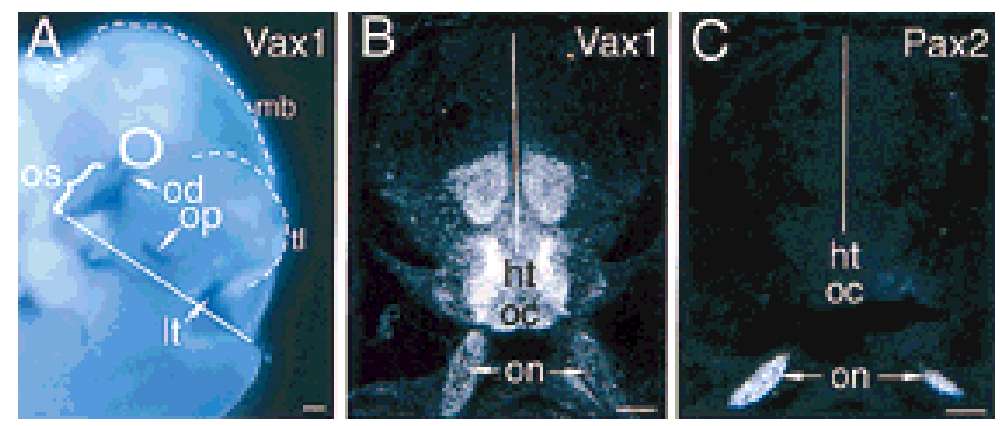

of the two optic nerves (on, arrows) and by midline cells at the optic chiasm (oc) and in the hypothalamus (ht). Note that there is high Vax1 expression at the junction between the optic nerve and the hypothalamus, and little Vax1 mRNA in the ventricular zone immediately adjacent to the third ventricle. $(C)$ Pax2 mRNA, in a frontal section adjacent to that of $B$, is evident in the same optic nerve cells (on, arrows) that express $\operatorname{Vax} 1$, but not at the optic chiasm or in the hypothalamus. Scale bars, $100 \mu \mathrm{m}$. 


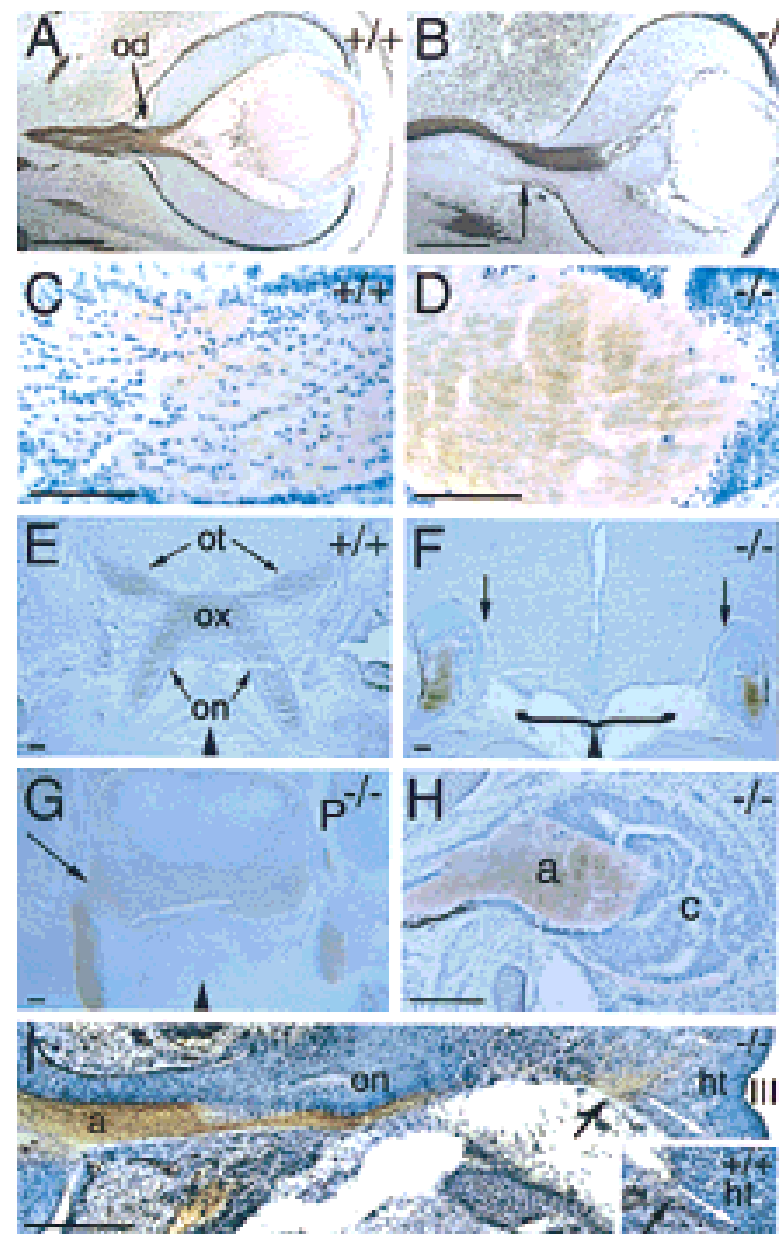

Figure 3. Defects in RGC axon pathfinding in Vax1 mutants. (A) Frontal section through an E13.5 wild-type eye (facing right). Retinal ganglion cell axons in the optic nerve (brown) are visualized with an antibody to L1. The optic disc (od) is indicated by the arrow. (B) Section through an E13.5 $\operatorname{Vax} 1$ mutant eye, similar to that in $A$. $\mathrm{L}^{+}$axons fasciculate in one restricted domain of the developing optic nerve, completely avoiding the $\mathrm{Vax}^{-1-}$ glial precursors of the nerve. Note that there is no longer a well-defined border between the eye and the optic nerve (apparent in $A$ ) and that aberrant retinal pigment epithelial cells are present at the periphery of the nerve (arrow). (C) High-power view of an E18.5 wild-type optic nerve, showing glial cells (toluidine blue stained, dark blue nuclei) interspersed among and regularly associating with $\mathrm{L}^{+}$retinal axons (light brown). (D) Similar section to that in $C$, but in a $\operatorname{Vax}^{-1-}$ optic nerve. Naked $\mathrm{L1}^{+}$axons entirely avoid and displace the glial and retinal cells of the nerve. $(E) \mathrm{L}^{+}{ }^{+} \mathrm{RGC}$ axons entering the wild-type E18.5 brain in the hypothalamus and crossing to the contralateral side of the brain at the optic chiasm (ox). The optic nerves (on) and the optic tract (ot) are indicated. $(F) \mathrm{L1}^{+}$retinal axons in Vax1 mutants (also at E18.5) do not form an optic chiasm and moreover, do not penetrate the brain but, instead, terminate in encapsulated bundles. The empty space beneath the floor of the hypothalamus is contiguous with the nasal cavity and is due to the cleft palate routinely seen in $V a \times 1^{-/-}$mice (bracket). Arrows indicate the pronounced cellular barrier separating the cap of RGC axons and the brain proper. $(G)$ Frontal section through the hypothalamus of E18.5 $\mathrm{Pax}^{-1-}$ mouse embryo. Unlike in the Vax1 mutant mice, retinal axons, identified by L1 staining, readily penetrate the brain (arrow), even though the Pax2 mutants lack an organized optic chiasm. Compare the difference at the insertion points (arrows) of the optic nerves between Vax1 mutants $(F)$ and Pax2 mutants $(G)$. (H) High-power image of the E18.5 Vax1 mutant cell cap, formed by optic nerve astrocyte precursors and displaced retinal cells, which encapsulate the RGC axons (a). At this stage, the thick cell cap (c) is a physical barrier preventing RGC axons from contact with the base of the brain. Note the presence of dark retinal pigment epithelial cells at the lower periphery of the distal end of the stunted optic nerve. (I) Tracing of the pioneer RGC axons that reach the hypothalamus in Vax1 mutants (-/ $)$ and in normal mice $(+/+$, inset) at E13.0. As shown in $B$, axons (a) and glial cells are separated in the optic nerve (on). Note that at this stage the cell cap at the distal end of the mutant optic nerve is not yet formed. As RGC axons reach the hypothalamus (ht), they splay out at the insertion point (black arrow), failing to fasciculate or to take the normal ventral pathway (white arrows in both montage and inset) toward the optic chiasm below the third ventricle (III). Black triangles at the bottom of $E-G$ indicate the position of the midline. Scale bars, $100 \mu \mathrm{m}$.

are naked and devoid of astrocytes, which are displaced to the periphery of the nerve (Fig. 3D). The particular geometric segregation of axons and glia varies from mutant nerve to nerve, in that bundles of bare axons are sometimes observed in the center of mutant nerves and are in other instances displaced to eccentric dorsal-ventral or nasal-temporal locations. In all cases, however, the axons are virtually devoid of associated optic nerve cells (Fig. 3D).

Optic stalk glial cells are not apparently lost as a consequence of mutation; there are roughly equal numbers of nuclei per optic stalk in wild-type and Vax1 mutant embryos at E11.5 (112 cells $/ 10^{4} \mathrm{\mu m}^{2}$ field in a wild-type longitudinal section vs. 106 cells $/ 10^{4} \mu \mathrm{m}^{2}$ field in an equivalent mutant section), and there is no measurable increase in the incidence of apoptosis in the mutants as assessed by TUNEL staining at E11.5, E13, and E18.5 (data not shown). In addition, the precursors of the stalk and nerve retain expression of Pax2 mRNA and protein and BF1 mRNA (see Fig. 7A,B, below), which are established markers for these cells (Torres et al. 1996; Mac- donald et al. 1997; Shimamura and Rubenstein 1997; Otteson et al. 1998; Marcus et al. 1999).

\section{$\mathrm{Vax}^{-/-}$RGC axons fail to enter the brain}

A second axon guidance phenotype becomes dramatically apparent as RGC axons approach the ventral diencephalon in the region of the presumptive hypothalamus, the site at which they normally enter the brain. This region is also an area of high Vax1 expression (Fig. 2B), which overlaps with optic chiasm and chiasmproximal markers such as RC2 and SSEA1 (see below). Pax2, although present in all mouse optic stalk cells after E12.5 (Otteson et al. 1998), is notably absent from the developing hypothalamus (Fig. 2C). The $\mathrm{Vax}^{+}$cells at the midline of the ventral diencephalon may be glial precursors, but this has yet to be established. By E18.5, wildtype RGC axons, visualized by an antibody to the cell adhesion molecule L1 (Bartsch et al. 1989), have penetrated the brain at this site and crossed at the optic chiasm to form the well-known X-shaped retinal projec- 
tion apparent in frontal sections (Fig. 3E). In Vax1 mutants, this projection is completely absent. RGC axons fail to penetrate the hypothalamus in significant numbers, and, instead, pile up in large, encapsulated lightbulb-shaped whorls that are physically isolated from the brain proper (Fig. 3F). These capped bundles are formed at the distal ends of the optic nerve from E14.5 through E18.5 as an increasing number of proliferating Pax $2^{+}$optic nerve glia and ingrowing $\operatorname{Pax}^{+}$retinal cells (see below) are displaced laterally. However, when the RGC axons initially reach the base of the brain, the caps are not present, and there is no obvious cellular or physical barrier to their penetration of the brain. As illustrated in the E13 montage of Figure 3I, these axons fail to fasciculate and extend toward the midline of the hypothalamus (Fig. 3I, inset), where they normally form the optic chiasm; instead, they appear to simply stall and then splay out at their normal entry point in the ventral diencephalon, as if responding to a chemical rather than a physical barrier. The basic size, shape, cellular density, and histology of the developing hypothalamus are not obviously altered in the Vax1 mutants, nor is its early dorsal-ventral or medial-lateral axial patterning affected (see Fig. 7, below).

The hypothalamic axon guidance defects seen in the Vax1 mutants are distinct from those evident in $\mathrm{Pax}^{-/-}$ mice or Noi (Pax2.1) mutant zebrafish, in that RGC axons in these Pax2 mutants readily enter the brain (Torres et al. 1996; MacDonald et al. 1997; Fig. 3G,H). The far more severe phenotype seen in the $\operatorname{Vax} 1^{-1-}$ mice, in which RGC axons fail to penetrate the brain and instead terminate in large whorls at the base of the hypothalamus (Fig. $3 \mathrm{H}$ ) is consistent with the fact that Vax1 is expressed at the midline of the developing hypothalamus, exactly where the optic nerve connects to the brain, whereas Pax2 is not (Fig. 2B,C). In keeping with these differences in mutant phenotype, we have found that Vax1 is normally expressed in the ventral diencephalon of mouse Pax2 mutants (data not shown).

\section{Coloboma in Vax1 mutants}

From their earliest stages of development, the eyes of Vax $1^{-/-}$homozygotes display coloboma-a failure of the eye to close at the choroid fissure (Fig. 4A), in which Vax1 expression in wild-type embryos is prominent (Hallonet et al. 1998). This coloboma persists throughout the life of the mutants. Nearly all $\operatorname{Vax}^{-/-}$mice die on the first day after birth (see below), but rare individuals ( $\sim 6 \%$ of the mutants) can survive for up to 2 weeks, and coloboma persists in these animals (Fig. 4B). Pax2 is also expressed at high levels in the optic disk, and $\mathrm{Pax}^{-/-}$ mice also display coloboma (Torres et al. 1996). Similarly, mutations in the human PAX2 gene account for a set of inherited colobomas that are associated with renal anomalies (Sanyanusin et al. 1995). As most instances of isolated coloboma in humans are not linked to the $P A X 2$ gene (Cunliffe et al. 1998), it is very possible that a subset of these disorders are caused by mutations in the human homolog of the mouse Vax1 gene. As in other instances
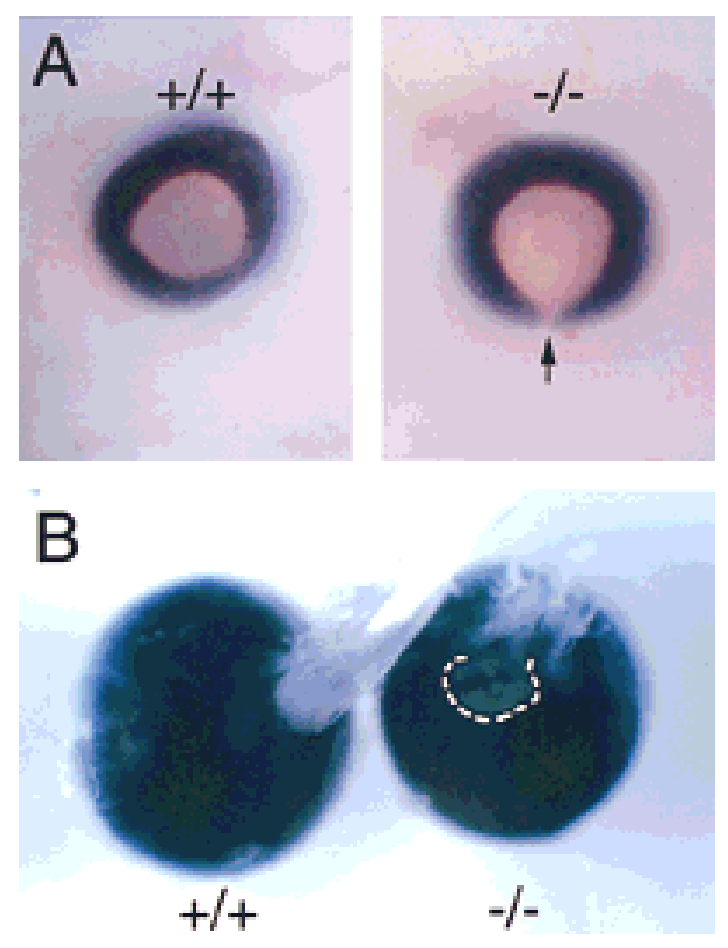

Figure 4. Homozygous Vax1 mutant mice show bilateral coloboma and disruption of the eye/optic nerve boundary. (A) Coloboma is evident at the pigmented back of an E13 mutant eye (arrow in $-/-$ ), due to the failure of the optic fissure to close. (B) Persistence of coloboma (broken line), together with poorly organized retinal axons in the optic nerve, in a dissected P12 mutant eye (-/-) with attached disordered nerve, as compared with the closed eye and well-formed optic nerve evident in P12 wild type $(+/+)$.

of coloboma (Torres et al. 1996; Macdonald et al. 1997), the failure of the optic disk to close disrupts the eye/ nerve boundary and results in an unsealed opening at the back of the eye through which retinal cells aberrantly migrate into the developing optic nerve (Figs. 2F and 8F, below). We have frequently observed cases in which the periphery of nearly the entire length of the Vax1 mutant nerve is pigmented by cells of the retinal pigment epithelium. In addition, $\mathrm{Pax}^{+}$cells, which are normally confined to the retina, are readily detected in the nerve, and by late embryogenesis, constitute a large fraction of the cells that encapsulate the stalled RGC axons at the base of the hypothalamus (see below).

\section{Neonatal death of $\mathrm{Vax1}^{-/-}$mice}

Although we have not determined why most Vax1 mutants die at birth, their immediate death may be due to the presence of a cleft palate, which is fully penetrant but is seen in varying degrees of severity among homozygous individuals (see, e.g., the open cavity at the base of the brain in Fig. 3F); severe cleft palate is generally a lethal phenotype in mice (Orioli et al. 1996). This developmental defect is almost always manifest in the secondary palate at the back of the oral cavity, which, as a 
consequence, is contiguous with the nasal sinuses. The observed cleft palate may be due to developmental failures associated with the transient expression of $\operatorname{Vax} 1$ in the first branchial arch (Hallonet et al. 1998). Its presence is of particular interest with regard to parallels between the Vax1 mutants and double-mutant mice in which the genes encoding the receptor tyrosine kinases EphB2 and EphB3 are both inactivated (see below).

\section{Fluorescent visualization of RGC afferents in $\mathrm{Vax}^{-1-}$ mice}

The dramatic failure in RGC axon penetration of the brain in the Vax1 mutants prompted us to examine this failure in greater detail, by fluorescently labeling these axons, through injection of the lipophilic axon tracer 1,1' -dioctodecyl-3,3,3', $3^{\prime}$-tetramethyl-indocarbocyanin perchlorate (DiI) into the retinae of both wildtype and mutant mice, at E16 in utero and on the day of birth (see Materials and Methods). These studies confirmed the failure of RGC axons to penetrate the brain at the base of the hypothalamus, to reach the chiasm at the midline, to cross contralaterally, or to make a stereotypical ipsilateral projection in the Vax1 mutants (Fig. 5AD). Instead, an analysis through successively more caudal coronal sections revealed that a small subset of $V_{a x} 1^{-/-}$RGC axons escape from the knot-like whorls evident in Figure $3 \mathrm{~F}$ and project ipsilaterally through regions of the preoptic area that are normally Vax1 negative; that is, through regions that are lateral to the $\operatorname{Vax} 1$ expression domains in Figure 2B. We speculate that these rare escapers might represent the first RGC axons to extend through the optic stalk in development. The few $\operatorname{Vax}^{-/-}$RGC axons that escape the knot are nonetheless completely blocked from crossing the midline and project exclusively to ipsilateral visual areas (Fig. $5 \mathrm{G}, \mathrm{H})$, in marked contrast to wild-type axons, $95 \%$ of which in the mouse cross at the chiasm and project to the contralateral side of the brain (Fig. 5E,F).

\section{$\mathrm{Vax}^{-/-}$axons fail to cross the anterior midline}

By mid-embryogenesis, expression of $\operatorname{Vax} 1 \mathrm{mRNA}$ at the midline is detected adjacent to a number of forebrain interhemispheric fiber tracts. For example, expression is detected adjacent to the lateral ventricles, and in the septum adjacent and immediately ventral to the developing corpus callosum (Fig. 6A,B; Hallonet et al. 1998). The failure of axons to enter the brain at the midline of the rostral hypothalamus in the $\operatorname{Vax} 1$ mutants prompted us to examine axon pathways in these anterior commissural axon tracts. We found that loss of Vax1 in these anterior midline regions similarly leads to a complete loss of interhemispheric connections in the mutant forebrain. Vax $1^{-/-}$mice, for example, lack a corpus callosum connecting the two cortical hemispheres (Fig. 6C,E). Instead, axons that would normally cross the midline in this thick tract terminate in large whorls of stunted axons that are deflected from the midline (asterisk in Fig. 6E). These so-called Probst bundles (Probst 1901) are
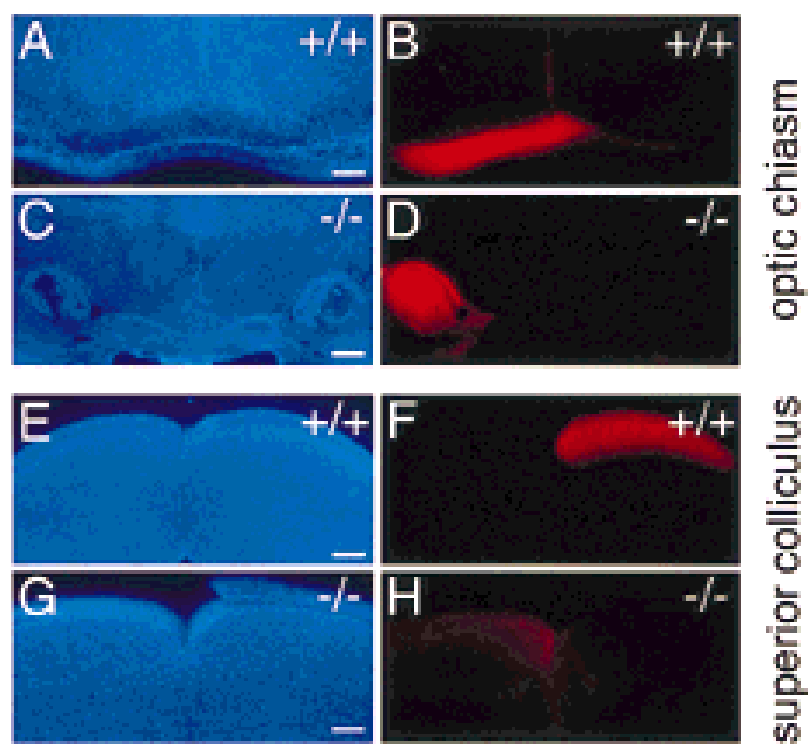

Figure 5. Growth of retinal ganglion cell axons into the brains of newborn wild-type $(+\mid+)$ and Vax1 mutant $(-/-)$ mice. The right eyes of newborn mice were completely filled with DiI to label the axons of all RGC neurons projecting from the right retina, and mice were analyzed 1 day later. (Similar injections were also performed and analyzed at mid-embryogenesis in utero; see Materials and Methods). $(A, B)$ Coronal section at the level of the optic chiasm in a wild-type newborn, stained with DAPI to label nuclei $(A)$ and visualized under rhodamine fluorescence to display DiI-labeled axons $(B)$. Axons transit through the optic chiasm normally. $(C, D)$ Coronal section similar to $A$ and $B$ but in a $\operatorname{Vax}^{-1-}$ newborn. Axons fail to enter the brain at this level and terminate in an encapsulated, light-bulb-shaped knot; the optic chiasm is completely absent. $(E, F)$ Coronal section, caudal to that of $A$ and $B$ at the level of the superior colliculus, in a wild-type newborn. Approximately $95 \%$ of labeled RGC axons cross to the opposite side of the brain at the chiasm and terminate in the contralateral superior colliculus $(F)$, as is normal in the mouse. $(G, H)$ Coronal section similar to $E$ and $F$ but in a $\operatorname{Vax}^{-1-}$ newborn. The rare axons that escape the knot in $D$ project through lateral regions of the ventral hypothalamus that are normally Vaxl negative (see Fig. 2B), and terminate exclusively in the ipsilateral superior colliculus $(H)$. Scale bars, $100 \mu \mathrm{m}$.

similar in histology to the capped light-bulb-like whorls of axons that develop at the base of the Vax 1 mutant hypothalamus. An equivalent failure in axon crossing at the hippocampal and anterior commissures, which are also normally apposed to populations of $\mathrm{Vax} 1^{+}$cells at the midline, is also consistently observed in the $\operatorname{Vax} 1$ mutants (Fig. 6D,F). In contrast, the commissures connecting the superior colliculi, which are caudal to the region of midline Vax1 expression (Hallonet et al. 1998), are intact in these mutants (data not shown).

\section{Essential features of midline axial patterning are preserved in $\mathrm{Vax}^{-/-}$mice}

What might account for the dramatic guidance defects seen in the optic nerve, optic chiasm, corpus callosum, 


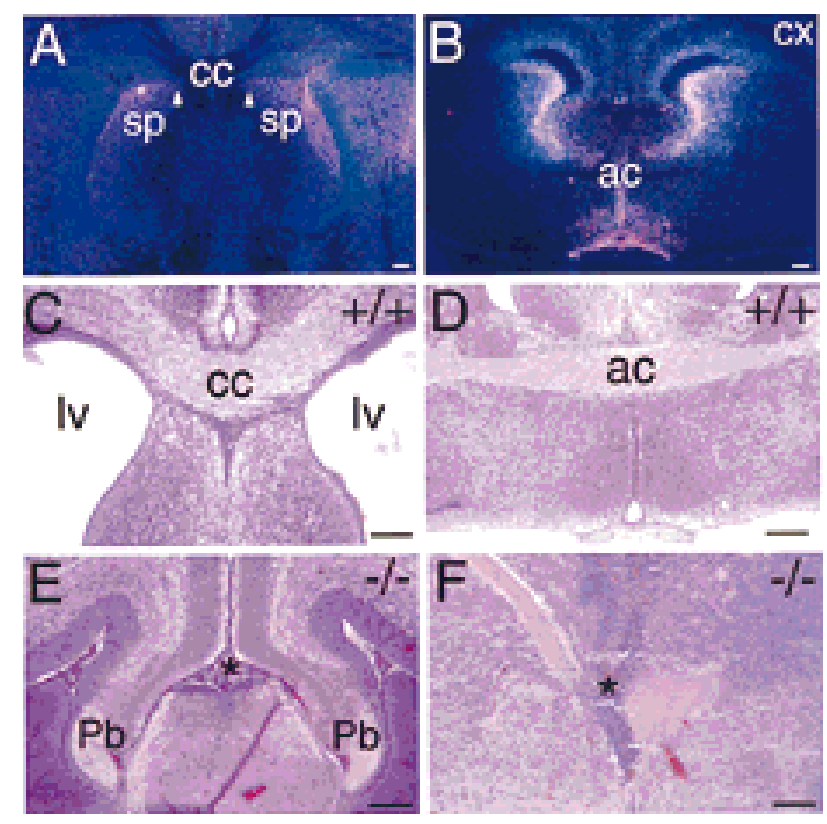

Figure 6. Anterior commissural fiber tracts fail to form in Vax1 mutant mice. (A) High-power view of in situ hybridization in neonatal brain (coronal plane) showing that $\operatorname{Vax} 1$ expression at the dorsal midline in the region of the septum (sp) and of the corpus callosum (cc) persists until birth. White arrowheads denote residual expression near the position of the midline glial sling of the embryo (Silver 1993). (B) Low-power view of a coronal section of an E16.5 mouse brain at the level of the anterior commissure (ac), showing Vax1 expression in midline cells surrounding the commissural tract. Note the lack of $\operatorname{Vax} 1 \mathrm{mRNA}$ in neurons of the developing cortex $(\mathrm{cx}) .(C)$ Coronal section through the corpus callosum (cc) of a wild-type neonatal mouse brain. At this stage, most of the axons responsible for the interhemispheric connections have crossed the midline, and a thick bundle of axons (cc) crossing the midline is visualized by hematoxylin and eosin staining. Note the open lateral ventricles (lv). (D) Coronal section through a neonatal wild-type mouse brain at the level of the anterior commissure (ac), illustrating the normal midline crossing of axons in this commissure. $(E)$ In Vax1 mutants, the corpus callosum fails to form. No axons cross the midline but, instead, turn away into the lateral ventricles and accumulate in Probst-bundles $(\mathrm{Pb})$ - thick knots of tangled axons adjacent to the dorsal midline. The point at which callosal axons would normally cross the midline is indicated by the asterisk. $(F)$ Same plane of sectioning as in $D$, but in a Vax1 mutant embryo in which axons fail to cross the midline in the anterior commissure. The normal midline crossing point is again indicated by the asterisk. Scale bars, $100 \mu \mathrm{m}$.

and hippocampal and anterior commissures of the $\operatorname{Vax} 1$ mutants? It should first be noted that in each of these forebrain regions, the observed axon pathfinding defects are almost certainly cell nonautonomous. The neurons in the developing cortex, hippocampus, and olfactory bulbs whose axons normally course through commissural tracts (e.g., those whose axons make up the corpus callosum) do not express Vax1 (Hallonet et al. 1998; Fig. 6A,B). Similarly, Vax 1 expression stops abruptly at the optic disk and is not detected in the neuroepithelium that gives rise to the neural retina (Hallonet et al.
1998; Fig. 2A), in which RGC neurons, whose axons are misrouted in the optic nerve and are blocked from entering the brain, are born. Instead, the Vax1 pathfinding defects appear to result from the loss of Vaxl from the midline cells with which axons and their growth cones normally interact.

As noted above, we have no evidence to support the hypothesis that the loss of Vax1 leads to the wholesale death of $\mathrm{Vax}^{+}$cells in any region of the forebrain. We also entertained the possibility that Vaxl might have a general structural role in patterning the ventral anterior midline. To address this possibility, we examined a battery of well-established cell fate and patterning markers that are expressed in the developing optic nerve, the rostral hypothalamus, and other $\mathrm{Vaxl}^{+}$regions at the midline (Marcus et al. 1999). These markers included the transcription factors $P a x 2, P a x 6, B F 1, D 1 \times 2, N k x 2.1$, and $N k x 2.2$, the chiasm markers RC2 and SSEA1, and the signaling protein Sonic Hedgehog (Shh).

We found that the $\operatorname{Vax} 1^{-/-}$optic disk and stalk are normally patterned along both the dorsal-ventral and nasal-temporal axes during early RGC axonogenesis, as assessed by the expression of Pax2 and BF1 in the E10-E12 stalk and disk (Torres et al. 1996; Shimamura and Rubenstein 1997; Marcus et al. 1999). When the optic stalk first forms as an extension of the diencephalon, Pax2 is initially expressed in its ventral but not dorsal aspect (Nornes et al. 1990), and this early dorsal-ventral patterning is maintained in the Vax1 mutants (Fig. 7A). [By E12.5, all normal optic stalk cells are $\mathrm{Pax}^{+}$(Otteson et al. 1998).] Similarly, the transcription factor BF1 is normally expressed in the nasal, but not the temporal, aspect of the early stalk, and this nasal-temporal gradient is also maintained in the mutants (Fig. 7B). We have observed that at later stages of embryonic development, a significant number of cells in the Vax1 mutant optic nerve express Pax6, which is normally confined to the retina proper (Walther and Gruss 1991). These Pax6 ${ }^{+}$ cells are first detected proximal to the developing retina (Fig. 8A), and later (by E14.5) frequently extend all the way to the brain (Fig. 8B). By this time, the developing mutant optic nerve contains both $\mathrm{Pax}^{+}$and $\mathrm{Pax}^{+}$cells (Fig. 8C,D). Although the presence of $\mathrm{Pax}^{+}$cells in the optic nerve might reflect a mispatterning event that proceeds in a lateral-to-medial graded fashion (beginning nearest the retina), we favor the alternative explanation that the unsealed hole at the back of the Vax1 mutant eye (the coloboma) allows for the unimpeded migration of retinal cells into the nerve (Fig. 8E,F). This interpretation is supported by the fact that (1) both Pax $6^{+}$cells and retinal pigment epithelial cells are always initially detected in development closest to the retina itself, (2) the number of these cells in the distal mutant nerve (nearest the brain) increases with developmental age, and (3) in contrast to wild type, the Vax1 mutant retina lacks a histologically apparent boundary with the optic nerve (Fig. 8E,F).

Consistent with the apparently normal axial patterning of the mutant optic stalk, we similarly found that nearly all of the markers of dorsal-ventral and anterior- 


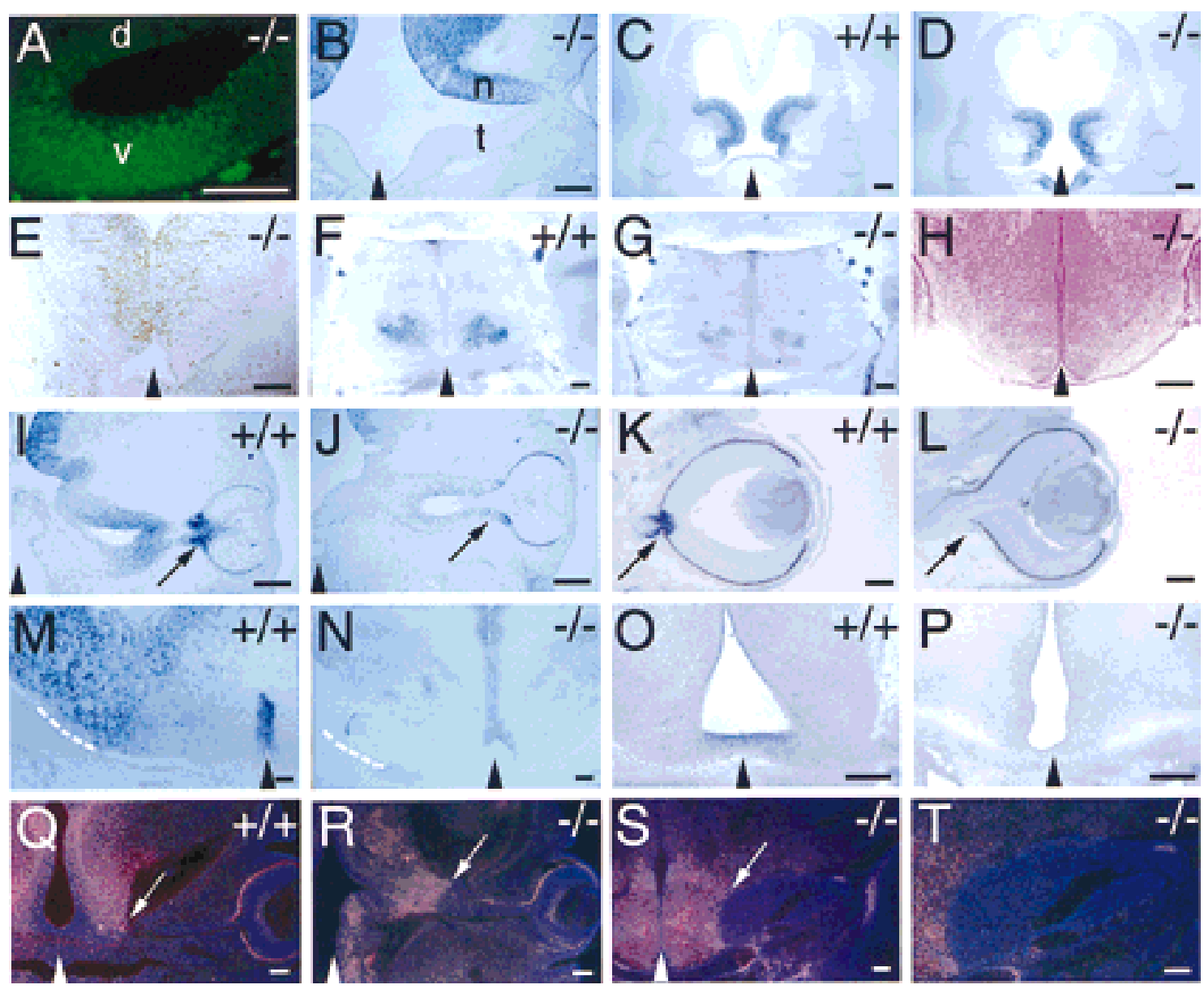

Figure 7. Cell fate and neural patterning in wild-type and Vax1 mutant embryos. Black triangles at the bottom of selected panels indicate the position of the midline. (A) High-power view of the E11 optic stalk of a Vax1 mutant $(-/-)$, illustrating a normal distribution of Pax2 expression in the ventral (v), but not dorsal (d), stalk. (B) Section of the E12 optic stalk of a Vax1 mutant (eye at extreme right), illustrating a normal distribution of BF1 expression in the nasal (n), but not temporal ( $\mathrm{t})$, stalk. $(C, D) N k x 2.1$ expression in frontal sections of the ventral diencephalon (presumptive hypothalamus) of a wild-type $(C,+/+)$ and Vax 1 mutant $(D,-/-)$ mouse at E12. (E) RC2 expression in a frontal section of the hypothalamus of a Vax1 mutant mouse at E13. Glial cells expressing the RC2 antigen are still present in a normal fashion in the mutant ventral diencephalon. $(F, G) N k x 2.2$ expression in frontal sections of the hypothalamus of a wild-type $(F,+/+)$ and a Vax1 mutant $\left(G_{,}-/-\right)$mouse at E19.5. (H) Coronal section of a E17.5 Vax1 mutant ventral diencephalon stained with hematoxylin and eosin showing normal histology in the area of Vax1 expression. $(I, I)$ Netrin-1 expression at the optic fissure and stalk of a wild-type $(I,+/+)$ and $\operatorname{Vax} 1$ mutant $(J,-/-)$ mouse at E12 sectioned in a frontal orientation. Eyes are pointing to the right; arrows indicate the optic fissure, which fails to close in the mutant. Note marked reduction of Netrin-1 in the mutant. $(K, L)$ Netrin-1 expression in the optic disk and proximal stalk of a wild-type $(K,+/+)$ and Vax1 mutant $(L,-/-)$ mouse at E14.5. Note complete absence of Netrin-1 in the mutant. Arrow in $K$ points to the expression of Netrin-1 in the closed optic disc, whereas the arrow in $L$ indicates the lack of Netrin-1 expression and the open fissure left at the eye/nerve boundary in the mutant embryos. $(M, N)$ High-power view of Netrin-1 expression in the hypothalamus of wild-type $(M,+/+)$ and Vax1 mutant $(N,-/-)$ mouse at E18.5, shown in a coronal cut. Note that in $N$, Netrin-1 expression in the lateral hypothalamus, at the entry point of the optic nerve (broken lines in $M$ and $N)$, is greatly reduced; surrounding the third ventricle, in which there is no overlap with Vax1 expression, this Netrin-1 expression is maintained. $(O, P)$ EphB3 receptor tyrosine kinase expression in wild-type $(O,+/+)$ and $\operatorname{Vax} 1$ mutant mouse $(P,-/-)$ in the ventral diencephalon at E13.5, shown in a coronal section. Expression of EphB3 is lost in the mutant embryo. $(Q, R)$ Coronal sections of Slit-1 mRNA expression, detected by radioactive in situ hybridization, in wild-type $(Q,+/+)$ and $V a x 1$ mutant $(R,-/-)$ mice at E13.5. Arrows indicate the optic nerve/hypothalamus boundary, which coincides with a pronounced border of Slit-1 expression. Note that in $R$, this sharp Slit-1 is maintained. $(S, T)$ Medium power $(S)$ and higher power $(T)$ view of Slit-1 expression, detected by radioactive in situ hybridization, in Vax1 mutant mice $(-/-)$ at E18.5. The Slit-1 boundary barrier (arrowed in $S)$ is maintained into late embryogenesis, at which point the capped bundle of RGC axons becomes directly wedged against it. Scale bars, $100 \mu \mathrm{m}$.

posterior axial patterning of the developing hypothalamus that we examined, including Shh, SSEA1, Nkx2.1, $N k x 2.2$, and RC2 are expressed in their normal, previ- ously described domains, both early and late in embryogenesis, in the Vax1 mutants. Representative examples for Nkx2.1 and RC2 are shown in Figure 7C-E. The ex- 


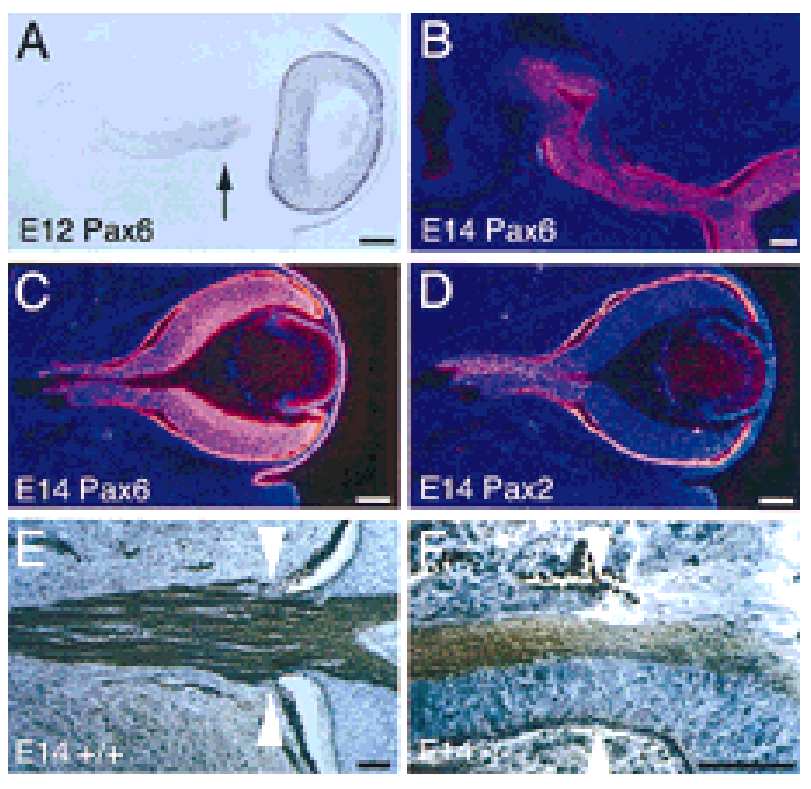

Figure 8. $\mathrm{Pax}^{+}$cells are ectopically present in the $\mathrm{Vax}^{-1-}$ optic nerve. (A) At E12, Pax6 mRNA (visualized by digoxigenin in situ hybridization) is detected in the mutant neural retina, as expected, but also in the optic stalk, immediately adjacent to the retina (arrow). The remainder of the mutant stalk (nearer the brain) is Pax6 $6^{-}$at E12. (B) By E14, ectopic Pax6 ${ }^{+}$cells (detected by ${ }^{33} \mathrm{P}$-labeled in situ hybridization) are present throughout the optic nerve. $(C, D)$ In the E14 mutant optic nerve, both ectopic $\operatorname{Pax}^{+}(C)$ and resident $\operatorname{Pax}^{+}(D)$ cells are present. The sections in $C$ and $D$ are adjacent. $(E)$ In the E14 wild-type embryo, a defined histological border (white arrowheads) is present between the eye and the optic nerve. Cells are stained with toluidine blue and axons immunostained with L1 antibody. (F) In E14 Vax1 mutants, the eye/nerve border is missing (white arrowheads indicate the normal location). Note that there is a continuum of histologically indistinguishable cells from the retina into the nerve, and also that pigment epithelium, which does not express either Vax1 or Pax6, streams into the nerve. Scale bars, $100 \mu \mathrm{m}$.

pression of two markers (Shh, Nkx2.2) appears to be subtly disordered and/or reduced in intensity by late embryogenesis in the $\operatorname{Vax} 1^{-/-}$mice (Fig. $\left.7 \mathrm{~F}, \mathrm{G}\right)$, but these effects may be in part accounted for by the lack of RGC axons at the optic chiasm. Their reduced expression notwithstanding, the boundaries of Shh and Nkx2.2 expression are very similar to wild type (Fig. 7F,G). Finally, the Vax $1^{-/-}$hypothalamus is largely indistinguishable from that of wild type in its general histology (Fig. $7 \mathrm{H}$ ). Together, these data suggest that the basic patterning of the ventral midline of the anterior CNS is not grossly effected by the loss of Vax1.

\section{Vax1 regulates expression of axon guidance cues}

As noted above, axons at the anterior midline of the Vax1 mutants grow as if they are repelled by populations of midline guidance cells to which they are normally attracted. This seeming conversion from attraction to repulsion led us to examine the expression of counterbalancing positive and negative axon guidance cues in $V a x 1^{-/-}$mice. This analysis yielded important insights into the axon pathfinding defects evident in the mutants. Perhaps the most significant alteration in the expression of a guidance cue that we observed is that for Netrin-1, an axon chemoattractant that is normally expressed by optic disk cells and stalk glial precursors, and to which RGC axons normally respond (Wang et al. 1996; de la Torre et al. 1997; Deiner et al. 1997). Expression of Netrin-1 by glial cells and their precursors in these structures is severely affected by the loss of Vax1 (Fig. 7I-L). As early as E12, Netrin-1 mRNA is markedly reduced in the $\operatorname{Vax} 1^{-/-}$optic disk and is nearly undetectable in the stalk (Fig. 7I,J), and by E14.5, this mRNA is no longer detectable in either structure (Fig. $7 \mathrm{~K}, \mathrm{~L}$ ). Netrin-1 is similarly expressed in the $\mathrm{Vax}^{+}$region of rostral hypothalamus in which the optic nerve normally enters the brain, and this expression is also lost in the Vax1 mutants (Fig. 7M,N). We have observed a similarly progressive loss of Netrin-1 expression, from E12.5 to E14, from all of the normally $\mathrm{Vax} 1^{+}$cells that we have examined in these mice but not from cells that are normally $\mathrm{Vax}^{-}$ (see Fig. 7N).

A second glial guidance cue that genetic experiments in the mouse have demonstrated to be important for axon guidance across the midline is the ephrin receptor EphB3, which, together with EphB2, is required for the formation of many of the same anterior commissural tracts (e.g., the corpus callosum) for which Vax1 is also essential (Orioli et al. 1996). In the forebrain, EphB3 is expressed by many of the same midline cells that express Vax1, including those of the septum that are just ventral to the developing corpus callosum (Orioli et al. 1996; Fig. 6A). Interestingly, double knockouts of $E p h B 2 / B 3$, in addition to exhibiting Vax1-like commissural tract defects, also display a Vax1-like cleft palate. Consistent with these parallels, we find that EphB3 expression at the midline of the hypothalamus is also exquisitely sensitive to the loss of $\operatorname{Vax} 1$ at all midline positions that are normally $\operatorname{Vax}^{+}$(Fig. 7O,P). Like Netrin-1, EphB3 is also expressed by cells that are not normally $\mathrm{Vax}_{1}^{+}$, and EphB3 expression is maintained in these cell populations in the Vax1 mutants (data not shown).

Although loss of Vax1 leads to the elimination of at least one attractive midline guidance cue, we find that the expression of the axon chemorepellent, Slit-1, is not affected in the hypothalamic midline of these mutants. Slit-1 appears to be particularly important for the regulation of axon pathfinding in this region of the CNS, because we have found that the border between the optic stalk/nerve and the ventral diencephalon (presumptive rostral hypothalamus) is delimited by a sharp boundary of Slit-1 expression (Fig. 7Q,R). As axons cross from the nerve into the brain, their axons move from a Slit- $1^{-}$to a strongly Slit-1 $1^{+}$zone, which is also $\operatorname{Vax}^{+}$(Fig. 2B) and Netrin- $1^{+}$. Whereas Netrin-1 expression in this region is lost in the Vax1 mutants (Fig. 7M,N), Slit-1 expression is robustly maintained, and the dense whorl of RGC axons that eventually develops is wedged against the Slit- $1^{+}$ 
cells at the midline of the mutant hypothalamus (Fig. 7S,T). Consistent with this pileup of RGC axons at the Slit-1 expression boundary, RGC neurons have recently been found to express Robo-2 (J. Braisted, T. Ringstedt, and D.D.M. O'Leary, unpubl.), one of two vertebrate homologs of the Drosophila Roundabout protein, which serves as the Slit receptor (Brose et al. 1999; Kidd et al. 1999; Li et al. 1999). Thus, for two regulators whose counterbalancing chemoattractive (Netrin) and chemorepellent (Slit) activities have been established both genetically and biochemically in Drosophila, the loss of Vaxl at the developing hypothalamic midline apparently shifts the balance of power in favor of chemorepulsion.

In vitro assay of axon guidance activity in $\mathrm{Vax}^{-/-}$mice

To assess whether the observed immiscibility of axons and glia in the Vax1 mutants might in fact reflect active chemorepulsion of the former by the latter, we performed a series of collagen gel experiments in which wild-type retinal explants were cocultured at a distance with optic stalk explants dissected from wild-type, heterozygous mutant, or homozygous mutant embryos at E11.5, E12.5, and E13.5 (see Materials and Methods). The results of these experiments are illustrated in Figure 9. We scored retinal axon outgrowth from a total of 75 cocultures after 4 days, and assigned the observed growth patterns to one of six categories-no axon outgrowth (ng in Fig. 91, growth strongly away from the optic stalk explant $(-2)$, growth weakly away $(-1)$, growth without preference (0), growth weakly toward $(+1)$, and growth strongly toward $(+2)$. Scoring was performed blind to genotypes. Our coculture results demonstrate a striking disparity between the axon guidance activities exhibited by wild-type and $\mathrm{Vax}^{-1-}$ optic stalk explants. A total of $56 \%(9 / 16)$ of retinal explants confronted with a wildtype optic stalk explant exhibited axon growth either weakly or strongly toward the explant, and none exhib- ited growth strongly away (Fig. 9). In marked contrast, only $12 \%(2 / 16)$ of retinae confronted with a mutant stalk exhibited growth either weakly or strongly toward the explant, whereas $63 \%$ exhibited growth either strongly or weakly away (Fig. 9). Significantly, of the 16 retinae that were placed near $\operatorname{Vax} 1^{-/-}$mutant stalk explants, 6 displayed growth strongly away from the explant. Note that the category distribution in Figure 9 is asymmetrically biased toward +2 for $\mathrm{Vax} 1^{+/+}$explants, and toward -2 for $V a \times 1^{-/-}$explants; it is centered around 0 for the $\operatorname{Vax} 1^{+/-}$explants.

\section{Discussion}

Vax1 is crucial for axon guidance in the developing mouse forebrain

The results described above demonstrate that Vax 1 is essential for the specification of axon trajectories in the developing mouse forebrain, particularly at and across the CNS midline. The inability of axons to interact productively with these midline regions is dramatically revealed by the failure of RGC axons to penetrate the brain at the ventral diencephalic midline and by the equivalent failure of axons that originate from neurons in the developing neocortex, hippocampus, and olfactory bulbs of the two cerebral hemispheres to cross the midline. As noted above, each of these failures occurs specifically at midline loci, either ventrally located (e.g., the presumptive hypothalamus) or more dorsally positioned (e.g., the septum apposed to the developing corpus callosum), which are populated by $\mathrm{Vax} 1^{+}$cells. In all cases that we have examined, the neurons whose growth cones and axons are prevented from crossing the midline are $\mathrm{Vax}^{-}{ }^{-}$, indicating that with respect to axon guidance defects, the effects of the Vax1 mutation are cell nonautonomous.

The identity of the majority of the $\mathrm{Vax}^{+}$guidance cells at the embryonic midline is, at this point, uncertain. Although they could be precursors to neurons or

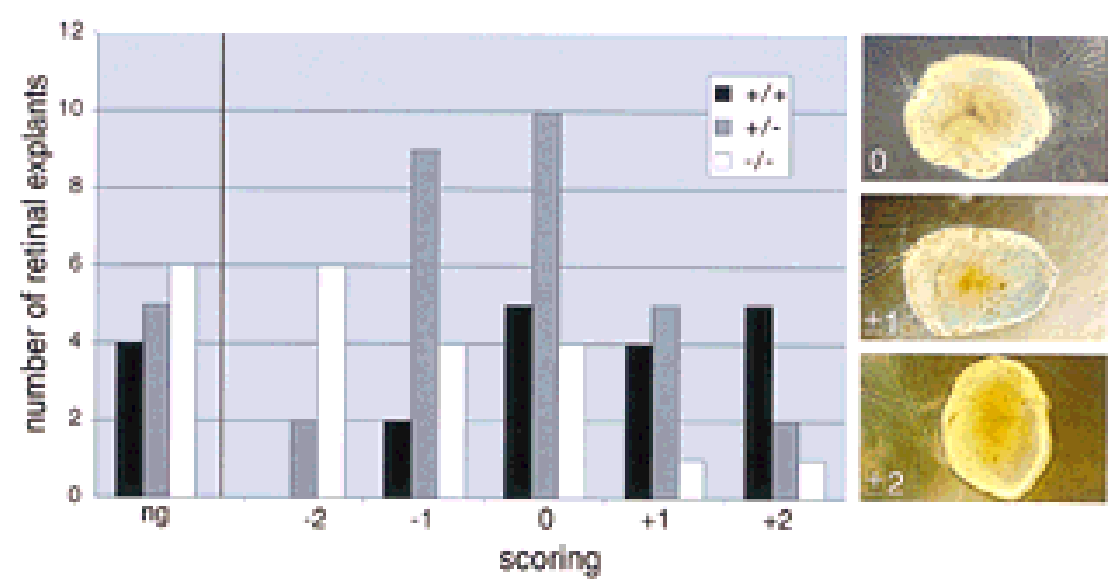

Figure 9. Collagen gel assay of retinal axon guidance by cells of wild-type and Vax1 mutant optic stalk; qualitative scoring of results. Wild-type retinae were positioned close to embryonic optic stalk explants from wildtype $(+/+$, black bars), heterozygous $(+/-$, gray bars), or homozygous (-/-, white bars) Vax1 mutant mice, and retinal axon outgrowth was scored after 4 days, as described in Materials and Methods. The histogram displays the number of retinal explants scored in six different categories: no growth (ng), strong away $(-2)$, weak away $(-1)$, unbiased $(0)$, weak toward $(+1)$, and strong toward $(+2)$. Retinal axon outgrowth is biased away from homozygous mutant optic stalk explants (categories -2 and -1 ), whereas growth of these same axons is inversely biased toward wild-type optic stalks $(+2$ and +1$)$. The outgrowth scores for the heterozygous explants exhibit an intermediate distribution. The three panels at right illustrate examples of retinal explants scored as unbiased (0), weakly biased (either toward or away) $( \pm 1)$, and strongly biased $( \pm 2)$. 
glia, or both, our bias is that many or all of these cells will prove to be glial precursors. As noted above, this is clearly the case for the $\mathrm{Vax}^{+}$cells of the optic stalk. A definitive identification of the $\mathrm{Vax} 1^{+}$cells at the midline of the developing CNS will require the development of a specific Vax1 antibody and its use in single-cell doublelabeling studies with midline glial markers.

\section{Vax1 target genes and their role in axon guidance}

We suggest that most or all of the axon guidance defects that result from the loss of Vax1 in midline cells are due to an attendant dysregulation of the genes encoding competing positive and negative guidance cues expressed in these midline cells. Our results demonstrate that one of these cues is Netrin-1, whose maintained expression at the midline of the early forebrain is clearly dependent on Vax1; by E14.5 in the Vax1 mutants, Netrin-1 expression can no longer be detected in the normally $\mathrm{Vax} 1^{+}$cells of the optic disk and stalk, the ventral diencephalon, and the midline cells abutting the forming anterior and hippocampal commissures and the corpus callosum. However, it is important to emphasize that whereas Vax1 may be essential for Netrin-1 expression in these forebrain regions, this dependence does not extend throughout the rostral-caudal extent of the neuraxis. There is abundant Netrin-1 expression in more caudal midline cells (e.g., those of the floor plate in the developing spinal cord) and in cells at the ventricular zone of the forebrain, which are $\mathrm{Vaxl}^{-}$, and these cells remain Netrin- $1^{+}$in the Vax1 mutants.

This caveat notwithstanding, there are interesting parallels between the Vax1 mutant phenotypes described above and the axon guidance defects reported for mouse Netrin-1 mutants. These latter mutants are also acallosal and also lack both anterior and hippocampal commissures, and the histology of these malformations is largely indistinguishable from those seen in $\mathrm{Vax}^{-1-}$ mice (Serafini et al. 1996). On some, but not all, genetic backgrounds, Netrin-1 mutants variably exhibit an axon guidance phenotype at the optic disk in which RGC axons do not even enter the optic stalk (Deiner et al. 1997); this difference between the Vax1 and Netrin-1 mutants may be due to the fact that low levels of Netrin-1 are still present in the E12 $\mathrm{Vax}^{1^{-/}}$optic disk at the time that the first RGC axons enter the stalk (Fig. 7I,J). In addition to the similarities in the Vax1 and Netrin-1 mutant phenotypes, our observation of the frequent coexpression of the two genes, and our finding that loss of Vaxl leads to a rapid extinction of Netrin-1 expression throughout the normally $\mathrm{Vax}^{+}$areas of the mutant CNS but not to the death of $\mathrm{Vax}^{+}$cells suggest that the Netrin-1 gene is an important target, either direct or indirect, of Vaxl action.

It should be noted, however, that this chemoattractant is likely to be only one of perhaps many guidance cues that are controled by Vax1. Our results demonstrate that expression of the receptor tyrosine kinase EphB3 is lost in the Vax1 mutants, specifically in those cells that are normally Vax $1^{+}$. Both Eph receptors and their ligands play important roles in axon guidance $/ \mathrm{O}^{\prime}$ Leary and
Wilkinson 1999), and mutation of the mouse EphB3 gene, in concert with the closely related EphB2 gene, leads to a set of midline axon-crossing phenotypes that are partially overlapping with those exhibited by Vax1 mutants (Orioli et al. 1996).

In the developing optic stalk and disk, the paired domain transcription factor Pax2 also appears to regulate Netrin-1 expression. As noted above, mouse Pax2 and zebrafish Pax2.1 are expressed by cells that form the optic disk and by glial precursors and their descendants in the optic stalk and nerve (Torres et al. 1996; Macdonald et al. 1997). Importantly, null mutations in the genes encoding these proteins lead to coloboma and also to axon guidance defects in the optic stalk that are similar to those seen in the Vax1 mutants; and in the zebrafish Noi mutant, the loss of Pax2.1 similarly has been shown to lead to a pronounced reduction in Netrin-1 expression in the developing optic stalk and nerve (Macdonald et al. 1997). Both Vax 1 and Pax2 would therefore appear to be necessary for glial differentiation in the optic nerve, although neither is sufficient.

As described above, axons in the Vax1 mutant forebrain appear to be repelled by the midline guidance cells with which they normally interact; axons and optic nerve glia are strictly segregated from one another in the mutant optic nerve despite their confined proximity, and axons that would normally form the corpus callosum and other interhemispheric commissures approach the midline but then fail to cross. This abject failure results in large whorls of tangled RGC axons at the base of the hypothalamus and in Probst bundles in place of a normal callosum. Although we suggest that the initial failure of growth cones to cross the midline at these loci is, for the most part, chemical in nature, it is very likely that the large encapsulated knots of axons that develop late in embryogenesis form a physical barrier to any subsequent commissural growth.

Our finding that a potent chemoattractant is lost from midline guidance cells at the same time that a potent chemorepellent is retained, suggests a straightforward hypothesis, namely, that the loss of Vax1 shifts the normally balanced presentation of attractive and repellent guidance cues at the anterior midline in favor of the latter. That is, axons now confront a sharp and discontinuous repulsive barrier at which the chemorepellent activities of molecules like Slit-1 are no longer modulated by the chemoattractant activities of cues such as Netrin-1. This hypothesis is strongly supported by the qualitative results of our collagen gel tests of retinal axon growth in response to confrontation with mutant versus wild-type optic stalk. In addition, it draws on compelling parallels to similar shifts in the balance of some of the same positive and negative midline cues that are seen in Drosophila mutants and is therefore one that we are currently pursuing in detail.

\section{Materials and methods}

Gene inactivation

The mouse Vax1 gene was cloned from a strain 129SV genomic 
library and was inactivated by deletion/replacement as diagrammed in Figure 1. The targeting vector was electroporated into W95 ES cells. Stable integrants were selected for using G418 (resistance to which is conferred by the neo cassette of Fig. 1), and nonhomologous integrants were selected against using FIAU (sensitivity to which is conferred by the thymidine kinase cassette of Fig. 1), both according to standard protocols (Tybulewicz et al. 1991). Four independent ES cell clones exhibiting homologous recombination of the targeting vector into the endogenous Vax1 gene, as assessed by Southern blot with the 5' external probe indicated in Figure 1, were injected into wildtype mouse blastocysts, which were in turn implanted into pseudopregnant foster mothers to generate high percentage chimeras, all by standard methods (Capecchi 1989). Mice analyzed in this report are $129 \mathrm{SV} \times \mathrm{C} 57 \mathrm{Bl} / 6$ hybrid strains. Given the very restricted CNS expression of $\operatorname{Vax} 1$, we assessed loss of Vax1 mRNA by in situ hybridization on sections cut through the hypothalamus of E13.5 mice, in which this is notably abundant. As a probe, we used a 540-bp BamHI-PstI fragment that spans part of the coding region, $330 \mathrm{bp}$ of which is predicted to be present in any mRNA that might be expressed from the knockout alleles.

\section{Expression studies}

In situ hybridization reactions with the indicated riboprobes, either digoxygenin-labeled or ${ }^{33} \mathrm{P}$-radiolabeled, were performed as described previously (Zhadanov et al. 1995; Braisted et al. 1997). The Pax 2 antibody was from Zymed, the RC2 and SSEA1 antibodies were developed by M. Yamamoto, (Massachusetts General Hospital, Boston, MA) and D. Solter, (Max-Planck Institute of Immunology, Freiburg, Germany) respectively, and were obtained from the Developmental Studies Hybridoma Bank, and the L1 antibody was a gift of C. Lagenauer (Pittsburgh Medical School, PA).

Dissected mouse embryos were anesthetized and immersion fixed in $4 \%$ paraformaldehyde/ $\mathrm{PBS}$ overnight at $4^{\circ} \mathrm{C}$, followed by overnight infiltration with $20 \%$ sucrose. Cryoprotected tissues were then embedded in OCT medium (Miles) and cut with a cryostat at $20 \mu \mathrm{m}$. Tissues were then postfixed in $4 \%$ paraformaldehyde for 5 min followed by three 5 -min washes in PBS.

Tissues were blocked with $10 \%$ normal goat serum $/ 0.1 \%$ Triton X-100 (Sigma) at room temperature for $1 \mathrm{hr}$. Primary antibodies were applied overnight at $4{ }^{\circ} \mathrm{C}(\mathrm{Pax} 2$ antiserum diluted $1: 400$ and $\mathrm{L} 1$ antiserum 1:2000 in $0.1 \%$ normal goat serum/ $0.1 \%$ Triton-X100). For bright-field microscopy, sections were incubated for $1 \mathrm{hr}$ with a biotinylated goat anti-rabbit secondary antibody and then for $30 \mathrm{~min}$ with an avidin-biotin-peroxidase complex (Vector Laboratories), followed by a 5 min reaction with enhanced DAB substrate (Boehringer Mannheim). Nuclei were counterstained lightly with toluidine blue, and sections were mounted with Permount (Fisher) and photographed. For fluorescence microscopy, immunolabeled sections were incubated for $1 \mathrm{hr}$ at room temperature with an FITC-conjugated anti-rabbit secondary antibody $1: 100$, Jackson ImmunoResearch).

\section{Axon tracing}

All RGC axons of a single (right) eye were labeled by filling the retina with the fluorescent lipophilic dye DiI, as described previously (Simon and O'Leary 1992). Complete filling of the retina and labeling of RGC neurons across its full dorsal-ventral and nasal-temporal extents was confirmed by fluorescent examination of the retinae $24 \mathrm{hr}$ after injection. Injections were performed both in utero at mid-embryogenesis (E16) and in new- born pups. Injected embryos and newborns were allowed to develop for $24 \mathrm{hr}$ after injection, either in utero (E17) or ex vivo (P1), at which time they were sacrificed, genotyped, perfused, and processed for analysis.

\section{Collagen gel assay}

Collagen gel assays were performed essentially as described previously (Sato et al. 1994). Briefly, retinae from E16 wild-type ICR mice were dissected and cut radially into eight pieces. Explants from optic stalks of wild-type, homozygous, and heterozygous Vax1 mutant embryos were obtained from stages E11.5, E12.5, and E13.5. Explants of retinae and optic stalks were cocultured in three-dimensional rat tail collagen matrices $(70 \mu 1)$. Collagen was mixed with $10 \times$ minimal essential medium (MEM) at a 9:1 ratio; this mixture was cooled in ice, and sodium bicarbonate was added just prior to positioning the explants to promote gelling. Gelled substrates were overlayed with $500 \mu \mathrm{l}$ of DMEM/F12 (GIBCO) supplemented with glutamine and 5\% rat serum. Cultures were maintained up to 4 days at $37^{\circ} \mathrm{C}$ in a humidified incubator in an atmosphere of $7.5 \% \mathrm{CO}_{2}$. After completion of retinal axon outgrowth, collagen cocultures were fixed in $4 \%$ paraformaldehyde $/ 0.1 \%$ glutaraldehyde and photographed with a phase-contrast microscope. Retinal outgrowth of all cocultures was scored qualitatively and binned into one of six different categories: no growth (ng), strong away (-2), weak away $(-1)$, no directional bias $(0)$, weak toward $(+1)$, and strong toward $(+2)$. A strong reaction of either polarity $( \pm 2)$ was scored when $>90 \%$ of the axons were clearly growing on one side, a weak reaction $( \pm 1)$ was scored when $60 \%-90 \%$ of the axons were found on one side, and no bias was scored when the distribution on either side was $50 \%$. All the scorings were done blind; the genotype of the optic stalk tissues was determined by Southern blot after the cultures were scored.

\section{Acknowledgments}

This work was supported by grants from the National Institutes of Health (G.L. and D. O'L.), by postdoctoral fellowships from the Italian Telethon Foundation (to S.B., grant 285/b) and the Swiss National Science Foundation (to R.H., grant 823A053456), and by the Medical Scientist Training Program at the University of California at San Diego (to S.M.). We thank Dr. Greg Dressler for providing Pax2 mutant brains; Dan Ortuño, Patrick Burrola, Darcie Baynes, and Todd Garvey for excellent technical assistance; Dr. Yasushi Nakagawa for in situ probes and helpful discussion; and our colleagues in the Lemke and O'Leary laboratories for advice, discussion, and support.

The publication costs of this article were defrayed in part by payment of page charges. This article must therefore be hereby marked "advertisement" in accordance with 18 USC section 1734 solely to indicate this fact.

\section{References}

Anderson, M.G., G.L. Perkins, P. Chittick, R.J. Shrigley, and W.A. Johnson. 1995. drifter, a Drosophila POU-domain transcription factor, is required for correct differentiation and migration of tracheal cells and midline glia. Genes \& Dev. 9: $123-137$.

Bartsch, U., F. Kirchhoff, and M. Schachner. 1989. Immunohistological localization of the adhesion molecules L1, N-CAM, and MAG in the developing and adult optic nerve of mice. $J$. Comp. Neurol. 284: 451-462.

Battye, R., A. Stevens, and J.R. Jacobs. 1999. Axon repulsion 
from the midline of the Drosophila CNS requires slit function. Development 126: 2475-2481.

Braisted, J.E., T. McLaughlin, H.U. Wang, G.C. Friedman, D.J. Anderson, and D.D.M. O'Leary. 1997. Graded and laminaspecific distributions of ligands of EphB receptor tyrosine kinases in the developing retinotectal system. Dev. Biol. 191: 14-28.

Brose, K., K.S. Bland, K.H. Wang, D. Arnott, W. Henzel, C.S. Goodman, M. Tessier-Lavigne, and T. Kidd. 1999. Slit proteins bind Robo receptors and have an evolutionarily conserved role in repulsive axon guidance. Cell 96: 795-806.

Capecchi, M.R. 1989. Altering the genome by homologous recombination. Science 244: 1288-1292.

Cunliffe, H.E., L.A. McNoe, T.A. Ward, K. Devriendt, H.G. Brunner, and M.R. Eccles. 1998. The prevalence of PAX2 mutations in patients with isolated colobomas or colobomas associated with urogenital anomalies. I. Med. Genet. 35: 806-812.

Deiner, M.S., T.E. Kennedy, A. Fazeli, T. Serafini, M. TessierLavigne, and D.W. Sretavan. 1997. Netrin-1 and DCC mediate axon guidance locally at the optic disc: Loss of function leads to optic nerve hypoplasia. Neuron 19: 575-589.

de la Torre, J.R., V.H. Hopker, G.L. Ming, M.M. Poo, M. TessierLavigne, A. Hemmati-Brivanlou, and C.E. Holt. 1997. Turning of retinal growth cones in netrin-1 gradient mediated by the netrin receptor DCC. Neuron 19: 1211-1224.

Dressler, G.R., U. Deutsch, K. Chowdhury, H.O. Nornes, and P. Gruss. 1990. Pax2, a new murine paired-box-containing gene and its expression in the developing excretory system. Development 109: 787-795.

Hallonet, M., T. Hollemann, R. Wehr, N.A. Jenkins, N.G. Copeland, T. Pieler, and P. Gruss. 1998. Vax1 is a novel homeobox-containing gene expressed in the developing anterior ventral forebrain. Development 125: 2599-2610.

Hummel, T., T. Menne, H. Scholz, S. Granderath, K. Giesen, and C. Klambt. 1997. CNS midline development in Drosophila. Perspect. Dev. Neurobiol. 4: 357-368.

Jacobs, J.R. and C.S. Goodman. 1989. Embryonic development of axon pathways in the Drosophila CNS. I. A glial scaffold appears before the first growth cones. I Neurosci. 9: 2402 2241.

Kidd, T., K.S. Bland, and C.S. Goodman. 1999. Slit is the midline repellent for the robo receptor in Drosophila. Cell 96: 785794.

Klambt, C. 1993. The Drosophila gene pointed encodes two ETS-like proteins which are involved in the development of the midline glial cells. Development 117: 163-176.

Klambt, C., J.R. Jacobs, and C.S. Goodman. 1991. The midline of the Drosophila central nervous system: A model for the genetic analysis of cell fate, cell migration, and growth cone guidance. Cell 64: 801-815.

Li, H.S., J.H. Chen, W. Wu, T. Fagaly, L. Zhou, W. Yuan, S. Dupuis, Z.H. Jiang, W. Nash, C. Gick et al. 1999. Vertebrate slit, a secreted ligand for the transmembrane protein roundabout, is a repellent for olfactory bulb axons. Cell 96: 807818.

Livesey, F.J. and S.P. Hunt. 1997. Netrin and netrin receptor expression in the embryonic mammalian nervous system suggests roles in retinal, striatal, nigral, and cerebellar development. Mol. Cell. Neurosci. 8: 417-429.

Macdonald, R., J. Scholes, U. Strahle, C. Brennan, N. Holder, M. Brand, and S.W. Wilson. 1997. The Pax protein Noi is required for commissural axon pathway formation in the rostral forebrain. Development 124: 2397-2408.

Marcus, R.C. and C.A. Mason. 1995. The first retinal axon growth in the mouse optic chiasm: Axon patterning and the cellular environment. J. Neurosci. 15: 6389-6402.

Marcus, R.C., R. Blazeski, P. Godement, and C.A. Mason. 1995. Retinal axon divergence in the optic chiasm: Uncrossed axons diverge from crossed axons within a midline glial specialization. J. Neurosci. 15: 3716-3729.

Marcus, R.C., K. Shimamura, D. Sretavan, E. Lai, J.L. Rubenstein, and C.A. Mason. 1999. Domains of regulatory gene expression and the developing optic chiasm: Correspondence with retinal axon paths and candidate signaling cells. J. Comp. Neurol. 403: 346-358.

Mason, C.A. and D.W. Sretavan. 1997. Glia, neurons, and axon pathfinding during optic chiasm development. Curr. Opin. Neurobiol. 7: 647-653.

Mi, H. and B.A. Barres. 1999. Purification and characterization of astrocyte precursor cells in the developing rat optic nerve. I. Neurosci. 19: 1049-1061.

Mitchell, K.J., J.L. Doyle, T. Serafini, T.E. Kennedy, M. TessierLavigne, C.S. Goodman, and B.J. Dickson. 1996. Genetic analysis of Netrin genes in Drosophila: Netrins guide CNS commissural axons and peripheral motor axons. Neuron 17: 203-215.

Nguyen Ba-Charvet, K.T., K. Brose, V. Marillat, T. Kidd, C.S Goodman, M. Tessier-Lavigne, C. Sotelo, and A. Chedotal. 1999. Slit2-Mediated chemorepulsion and collapse of developing forebrain axons. Neuron 22: 463-473.

Nornes, H.O., G.R. Dressler, E.W. Knapik, U. Deutsch, and P. Gruss. 1990. Spatially and temporally restricted expression of Pax2 during murine neurogenesis. Development 109: 797-809.

O'Leary, D.D.M. and D.G. Wilkinson. 1999. Eph receptors and ephrins in neural development. Curr. Opin. Neurobiol. 9: 65-73.

Ono, K., Y. Yasui, U. Rutishauser, and R.H. Miller. 1997. Focal ventricular origin and migration of oligodendrocyte precursors into the chick optic nerve. Neuron 19: 283-292.

Orioli, D., M. Henkemeyer, G. Lemke, R. Klein, and T. Pawson. 1996. Sek4 and Nuk receptors cooperate in guidance of commissural axons and in palate formation. EMBO J. 15: 60356049.

Otteson, D.C., E. Shelden, J.M. Jones, J. Kameoka, and P.F. Hitchcock. 1998. Pax2 expression and retinal morphogenesis in the normal and Krd mouse. Dev. Biol. 193: 209-224.

Pfeffer, P.L., T. Gerster, K. Lun, M. Brand, and M. Busslinger. 1998. Characterization of three novel members of the zebrafish Pax2/5/8 family: Dependency of Pax5 and Pax8 expression on the Pax2.1 (noi) function. Development 125: 3063-3074.

Probst, M. 1901. Über den Bau des balkenlosen Grosshirns, sowie über Mikrogyrie und Heterotypie der grauen Substanz. Arch. Psychiatr. 34: 709-786.

Raff, M.C. 1989. Glial cell diversification in the rat optic nerve. Science 243: 1450-1455.

Rothberg, J.M., J.R. Jacobs, C.S. Goodman, and S. ArtavanisTsakonas. 1990. Slit: An extracellular protein necessary for development of midline glia and commissural axon pathways contains both EGF and LRR domains. Genes \& Dev. 4: $2169-2187$

Sanyanusin, P., L.A. Schimmenti, L.A. McNoe, T.A. Ward, M.E. Pierpont, M.J. Sullivan, W.B. Dobyns, and M.R. Eccles. 1995. Mutation of the PAX2 gene in a family with optic nerve colobomas, renal anomalies and vesicoureteral reflux. Nat. Genet. 9: 358-364.

Sato, M., L. Lopez-Mascaraque, C.D. Heffner, and D.D.M O'Leary. 1994. Action of a diffusible target-derived chemoattractant on cortical axon branch induction and directed growth. Neuron 13: 791-803. 
Serafini, T., S.A. Colamarino, E.D. Leonardo, H. Wang, R. Beddington, W.C. Skarnes, and M. Tessier-Lavigne. 1996. Netrin-1 is required for commissural axon guidance in the developing vertebrate nervous system. Cell 87: 1001-1014.

Shimamura, K. and J.L. Rubenstein. 1997. Inductive interactions direct early regionalization of the mouse forebrain. Development 124: 2709-2718.

Silver, J. 1993. Glia-neuron interactions at the midline of the developing mammalian brain and spinal cord. Perspect. Dev. Neurobiol. 1: 227-236.

Silver, J. and M.Y. Ogawa. 1983. Postnatally induced formation of the corpus callosum in acallosal mice on glia-coated cellulose bridges. Science 220: 1067-1069.

Silver, J., M.A. Edwards, and P.J. Levitt. 1993. Immunocytochemical demonstration of early appearing astroglial structures that form boundaries and pathways along axon tracts in the fetal brain. J. Comp. Neurol. 328: 415-436.

Simon, D.K. and D.D.M. O'Leary. 1992. Development of topographic order in the mammalian retinocollicular projection. J. Neurosci. 12: 1212-1232.

Small, R.K., P. Riddle, and M. Noble. 1987. Evidence for migration of oligodendrocyte-type-2 astrocyte progenitor cells into the developing rat optic nerve. Nature 328: 155-157.

Soriano, N.S. and S. Russell. 1998. The Drosophila SOX-domain protein Dichaete is required for the development of the central nervous system midline. Development 125: 3989-3996.

Tear, G., R. Harris, S. Sutaria, K. Kilomanski, C.S. Goodman, and M.A. Seeger. 1996. Commissureless controls growth cone guidance across the CNS midline in Drosophila and encodes a novel membrane protein. Neuron 16: 501-514.

Torres, M., E. Gomez-Pardo, and P. Gruss. 1996. Pax2 contributes to inner ear patterning and optic nerve trajectory. Development 122: 3381-3391.

Tybulewicz, V.L., C.E. Crawford, P.K. Jackson, R.T. Bronson, and R.C. Mulligan. 1991. Neonatal lethality and lymphopenia in mice with a homozygous disruption of the c-abl protooncogene. Cell 65: 1153-1163.

Walther, C. and P. Gruss. 1991. Pax-6, a murine paired box gene, is expressed in the developing CNS. Development 113: $1435-1449$.

Wang, L.C., J. Dani, P. Godement, R.C. Marcus, and C.A. Mason. 1995. Crossed and uncrossed retinal axons respond differently to cells of the optic chiasm midline in vitro. Neuron 15: 1349-1364.

Wang, L.C., R.A. Rachel, R.C. Marcus, and C.A. Mason. 1996. Chemosuppression of retinal axon growth by the mouse optic chiasm. Neuron 17: 849-862.

Winberg, M.L., K.J. Mitchell, and C.S. Goodman. 1998. Genetic analysis of the mechanisms controlling target selection: Complementary and combinatorial functions of netrins, semaphorins, and IgCAMs. Cell 93: 581-591.

Wu, W., K. Wong, J. Chen, Z. Jiang, S. Dupuis, J.Y. Wu, and Y. Rao. 1999. Directional guidance of neuronal migration in the olfactory system by the protein Slit. Nature 400: 331-336.

Zhadanov, A.B., S. Bertuzzi, M. Taira, I.B. Dawid, and H. Westphal. 1995. Expression pattern of the murine LIM class homeobox gene Lhx3 in subsets of neural and neuroendocrine tissues. Dev. Dyn. 202: 354-364.

Zinn, K. and Q. Sun. 1999. Slit branches out: A secreted protein mediates both attractive and repulsive axon guidance. Cell 97: $1-4$. 


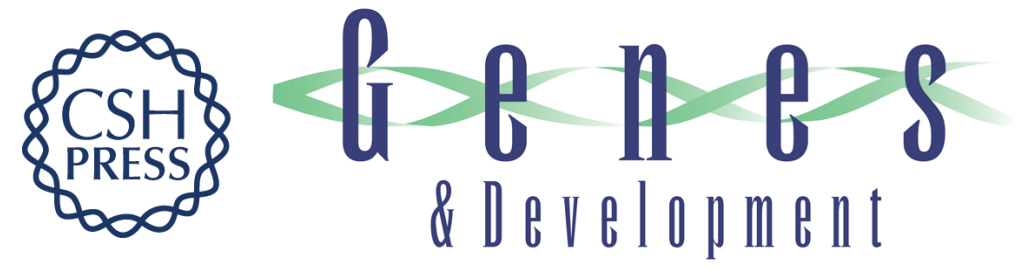

\section{The homeodomain protein Vax1 is required for axon guidance and major tract formation in the developing forebrain}

Stefano Bertuzzi, Robert Hindges, Stina H. Mui, et al.

Genes Dev. 1999, 13:

References This article cites 55 articles, 22 of which can be accessed free at:

http://genesdev.cshlp.org/content/13/23/3092.full.html\#ref-list-1

License

Email Alerting Receive free email alerts when new articles cite this article - sign up in the box at the top Service right corner of the article or click here.

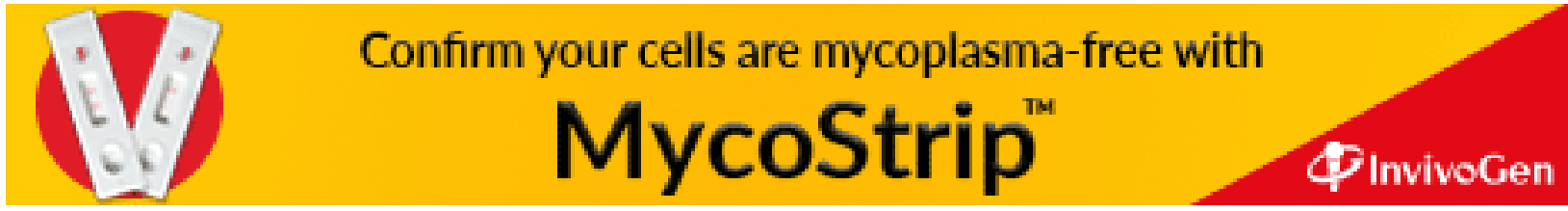

